\title{
Developments in Solid Earth Sciences of Japan during the period 1967-1968
}

\author{
(Report submitted to the Standing Committee on Solid \\ Earth Sciences, Pacific Science Association) \\ By \\ Tatsuro MAtsumoto* and Seiya UYedA**
}

Since we reported last time (1966), considerably great advances have been shown in various fields of solid earth science, of which the following may exemplify relevant achievements in Japan.

(1) Some, if not all, of the geological and geophysical papers presented at the 11 th Pacific Science Congress, Tokyo, have been published as follows:

HATAI, K. [Ed.] (1967): Tertiary correlations and climatic changes in the Pacific [Symposium No. 25], 102 pp., Sasaki, Sendai.

IKEBE, N. [Ed.] (1967) : Sea level changes and crustal movements of the Pacific during the Pliocene and post-Pliocene time [Symposium No 19]. Jour. Geosci., Osaka City Univ., 10, (1), 1-134.

KNOPOFF, L., C. DRAKE and P. J. HART [Ed.] (1968): The crust and upper mantle of the Pacific area based on the Upper Mantle Project Symposium, Tokyo, August 1966, Geophysical Monograph 12, 522 pp., American Geophysical Union, Washington D. C.

Matsumoto, T. [Ed.] (1967): Age and nature of the circum-Pacific orogeneisis [Symposium No. 24]. Tectonophysics, 4, (6-7) (special issue), 315-623.

Minato, M. et al. [Ed.] (1968) : Pacific Geology, 1, Tsukiji-Maruzen, Tokyo. Nagata, T. [Ed.] (1967) : Proceedings of the syposium on Pacific Antarctic Sciences. Jap. Antarc. Res. Exp., Sci. Rep., Special issue (1), 275 pp.

(2) As a result of recent researches geophysical and geological data in and around the island arc of Japan have been compiled in a concise form by RIKITAKE et al. $(1967,1968)$ on the occasion of a UMP symposium. The paper contains a list of recently published references as well as summarized illustrations.

(3) Succeeding to the geophyscial investigation across the Japan trench (LUDWING et al. 1966), the crustal structure of the Philippine Sea has been

* Department of Geology, Kyushu University, Fukuoka

** Earthquake Research Institute, University of Tokyo 
made clear by the same group of scientists (MURAUCHI et al. 1968) through a number of seisimic refraction profiles. The basins of the Philippine Sea have fairly normal oceanic crust that includes, between the sea floor and layer 2, a layer of about $3.5-\mathrm{km} / \mathrm{sec}$ velocity controlling the characteristic rough topography. Crustal thickening beneath the Nansei Shoto, Oki-Daito, Kyushu-Palau, and the Honshu-Mariana ridges is associated mainly with an increase in thickness of the $3.5-\mathrm{km} / \mathrm{sec}$ layer and a thick underlying section of material with a velocity of $5.5-6.0 \mathrm{~km} / \mathrm{sec}$.

(4) Oceanographic researches are being undertaken through modernized techniques around the Japanese islands. New geological lines of information, among others, are as follows: (a) Hydrographic Office (1967) published two sheets of chart, H. O. 6301 and 6302, which show details of submarine topography around the Japanese islands, such as basins, troughs, trenches, ridges, banks, marginal plateaus, submarine fans, submarine canyons and deep sea channels. (b) The submarine geology of the southeastern part of the Japan Sea has been recently described in detail by IwABUCHI (1968). (c) Thick sediments are recognized in troughs off the Japan Sea coast, Nankai trough, and also submarine terraces of $1000 \mathrm{~m}$ and $2000 \mathrm{~m}$ depth on the continental slope off the Pacific coast (DEN et al., 1968, IWABUCHI, 1968). Embedding by turbidite is considered by several geologists (e.g. SATO, 1968). (d) Cretaceous (Aptian?) nerineid, Plesioptygmatis sp., and calcareous algae were discovered on Seamount Sysoev (Erimo) at the junction of Japan and Kuril-Kamchatka trenches (TSUCHI and KAGAMI, 1967).

(5) The Ocean Research Institute, University of Tokyo, constructed the Hakuho-maru, a new, well equipped vessel of 3225 tons. Her first scientific cruise across the western Pacific in 1967 has brought back fruitful new data, of which geological ones have been preliminarily reported by NASU et al. 1968 (oral communication).

(6) With the aid of tetrahedral anvil-type high-pressure apparatus designed at the Institute of Solid State Physics, University of Tokyo, АкIмото and FUJISAWA (1968) studied olivine-spinel solid solution equilibria in the system $\mathrm{Mg}_{2} \mathrm{SiO}_{4}$ $\mathrm{Fe}_{2} \mathrm{SiO}_{4}$ over the pressure range 43 to $96 \mathrm{~Kb}$ at $800^{\circ}, 1000^{\circ}$, and $1200^{\circ} \mathrm{C}$. The olivine-spinel transition accounts for the sharp discontinuity that starts at the depth of about $370 \mathrm{~km}$ in the mantle and whose thickness is of the order of several tens of kilometers, as discussed by FuJisAWA (1968). The location and the sharpness of discontinuities in the transition layer expected from the recent progress of high-pressure mineralogy show a substantial agreement with the recent results of investigation about the upper mantle structure from apparent velocities of $\mathrm{P}$ waves recorded at Wakayama Micro-Earthquake Observatory 
(KANAMORI, 1967).

(7) An international meeting was held at Hakone, May, 1968, on lead and strontium isotopes in basaltic and granitic rocks of the circum-Pacific region, with attendance of specialists from Japan, U. S. A., Canada and Australia. The proceedings and abstracts of the presented papers are briefly published (KUNO et al. 1968), giving the following results, among others. (a) The Cretaceous granites of Japan are interpreted, on isotope geochemical evidence, to have been largely derived from the mantle material in some age not much older than the Cretaceous times and not from the underlying older sialic material. (b) The chemical analyses of rocks from selected volcanoes along E-W traverses across central and northern Japan show that the observed ${ }^{238} \mathrm{U} /{ }^{204} \mathrm{~Pb}$ ratio of tholeiitic basalt from the east end of the traverse is low while that of alkaline basalt from the west is high and that the isotopic composition of lead becomes successively less radiogenic from the oceanic to the continental side.

(8) Earthquakes occurred in swarms during the period of 1966-68 in a local place called Matsushiro in central Japan. They have been intensively investigated by a group of scientists who have published serial reports (1966-67) and also a summary of seismographic observation (HAGIWARA and IWATA, 1968).

(9) VACQUIER and UYEDA (1967) investigated the palaeomagnetism of nine seamounts in the western Pacific and of three volcanoes in Japan. The difference they found in latitude between the pole positions of the group of seamounts in the Pacific basin proper and those in the Philippine-Shikoku basin west of Izu-Bonin arc can be interpreted as caused by a northerly drift of the Pacific ocean floor. SASAJIMA et al. $(1966,1968)$ studied the palaeomagnetism of the Cretaceous and older Tertiary volcanic rocks in southwest Japan, giving a tentative conclusion about the periodic occurrence of reversal NRM and a hypothesis of a drift of the Honshu island relative to the east Asiatic continent since the Cretaceous.

(10) Numerous geochronological data have been added since the last report. The remarkable results, among others, are $\mathrm{Rb}-\mathrm{Sr}$ ages of $400-450$ million years of granitic and metamorphic rocks occurring as narrow, lenticular, squeezed out masses along thrusts in southwest Japan (HAYASE et al., 1967) and those of $500 \mathrm{~m} . \mathrm{y}$. or more of certain rocks occurring probably as relicts in the generally 175-195 and 240 m.y. gneiss and granite of the Hida area (MATsumoto et al., 1968; SATO, 1968). A bibliography of geochronological data in Japan -1 (MATSUMOTO [Ed.], 1968) is now available.

(11) On the basis of a number of works in structural geology KIMIJRA (1968) discussed about the folded zones and folding styles in Japan and has concluded that the large scale structure as manifested by "Faltenspiegel" is rather 
flat but displaced by major faults which separates major tectonic zones. In the meanwhile a tectonic map of Japan, on scale 1:2,000,000, was published by the Geological Survey of Japan (1968), although the way of tectonic division seem to have been depended much on a personal view of the compiler (IsOMI).

(12) The Geological Survey published another, excellently compiled map on the same scale, showing the distribution of petrologically classified volcanoes of Japan. This is complementary with a selected bibliography of Japanese volcanoes published at the same time by the same office. Of numerous papers and maps published by the Geological Survey, geological map of Mt. Fuji, scale $1: 50,000$, with an explanatory text (TSUYA, 1968), may be one of the outstanding contributions.

(13) In the field of mineralogy and petrology the zoolite facies metamorphism is intensively studied. Interesting facts are being found from careful field work in the Tertiary green tuff areas in northeast Japan and the thick Cretaceous sedimentary areas in southwest Japan as well as from laboratory work in synthesis of minerals (e.g. HARADA, 1968; IIJIMA and UTADA, 1967; NAKAJIMA, 1968 ; SeKI, 1968; UTAdA, 1968; UtAdA et al., 1967). Mineral zones or metamorphic types are distinguishable in accordance with the burial depth and geothermal gradient. More experimental studies on other kinds of mineral (e.g. KANO and NAMBU, 1967-68; MizuTANI, 1966; YAGI and ONUMA, 1967) have given fundamental information on igneous and sedimentary petrology as well as on mineralogy.

(14) Succeeding to the previous period, the geological and palaeontological reconnaissance in southeast Asia has been carried on mainly by members of the Association for Palaeontological Research in Southeast Asia (established in 1966, with office at the Department of Geology, Kyushu University, Fukuoka). The results have been published in vols. 3 (1967) and 4 (1968) of "Geology and Paleontology of Southeast Asia" (Univ. Tokyo Press) and also in some journals.

(15) For brevity advances in palaeontology and biostratigraphy have to be largely omitted from the present report, except for the following short remarks : (a) the rich echinoid faunas from Japan and adjecent regions, fossil and recent, were described by Nishiyama $(1966,67)$. (b) The Desmostylia, peculiar, Miocene, northern Pacific mammals, were described and discussed by SHIKAMA (1966). (c) Study of Nannofossil by electron microscope has been much improved (see Honjo et al., 1967 ; TAkayama, 1967 ; also Fischer et al., 1967). (d) Attempts in palaeohistology and isotope palaeontology are being undertaken by some groups of scientists in Japan. This is primarily concerned with biological problems, but the results would have, for instance, relations with the sedi- 
mentological and other problems in earth science.

(16) Apology should be extended to omission of writing about many valuable works other than aforementioned. Finally the following two publications may give retrospect, present status, and prospect in some aspects of earth sciences in Japan, although they are written in Japanese primarily for domestic purpose. :

Seism. Soc. Japan (1967) : Seismology in Japan. J. Seism. Soc. Japan, [2], 20, (4), special issue, 1-326.

Geol. Soc. Japan (1968): Geological sciences in Japan - Past, present and future, $610 \mathrm{p}$.

The last one was published to commemorate the 75 th anniversary of the Society. They started to issue a new series of publication "Memoirs of the Geological Society of Japan" and Nos. 1-3 (1968) (in Japanese with English abstract) have already been published, which contain papers of symposia.

\title{
1967-1968 年間日本における固体地球科学の進歩
}

\section{（太平洋学術協会固体地球科学常置委員会に提出した報告）}

\author{
松 本 達 郎・上 田 誠 也
}

\section{解 説}

太平洋学術協会固体地球科学常置委員会委員長 W. H. MATHEWS 教授の要請にこたえ, 1969年 1 月 15 日に同委員長に提出した報告をここに揭載 した。この報告は, 太平洋ならびに環太平洋地域 に関する固体地球科学諸分野の1967-1968年間に おける研究成果の中で, 著しい進歩を選んで要点 を紹介し，また研究機関・重要施設・学協会など が新設された場合には，それをも報告するよう に，各国の委員宛に委員長から要請があつたのに 対し回答したものである。その報告核数ページ程 度の簡潔な文章であるよう要望されていた。事実 各国委員からの報告に基づき，MATHEWS 委員 長がまとめた常置委員会としての報告文は, きわ めて短いものである。その委員長報告は今はまだ 謄写版であるが，いずれ何かに印刷公表されるべ きである。日本の 2 委員から報告した内容を，関 心ある方々知つて戴き，批判を仰ぐことが必要
であると考え，委員長の諒解を得て，なまの原文 のままここに揭載した次第である。

この原稿は主として松本が執筆し，上田がこれ を読み直して若干の修正をした。きわめて多くの 貴重な研究成果がある中で, 私たちの考で取捨選 択し，乙かも限られた紙面に紹介することは，卒 直に言つて困難がある。またメ゙切期日に制約され て，1968年度中に公表されていながら，私たちの 読むことのできなかつた文献もあるにちがいな い。不備の点は次回報告の際補うことも可能であ るから, 研究者からの御申出を打願いする。なお 2 年後の次回報告文作成関しても, 研究者から の特別な御申出があれば，参考にしたいと考えて いる。

なおこの委員会は, 以前は地質学・地球物理学 常置委員会と称していたが，第11回太平洋学術会 議（東京）の際, 固体地球科学常置委員会と改称 された。前回の報告は, 当時の委員長故久野久教 授がまとめて, 次記のものに公表されているか 